\title{
DOES ECONOMIC GROWTH HAS AN IMPACT ON EAST JAVA REGIONAL REVENUE?
}

\author{
Faishal Fadli \\ Brawijaya Economics and Business Faculty \\ faishalfadli@ub.ac.id
}

\begin{abstract}
The implementation of regional autonomy resulted in each region to be able to manage their finances independently. This is one way the central government to remove the dependency of local governments to the central government. Thus requiring local governments to explore the sources of local revenue in order to finance regional development. In an effort to increase local revenues derived from the PAD is determined by economic factors or economic potential which has the prospect to be developed for each area. The result indicates the role of the revenue $(P A D)$ in the Regional Budget (APBD) of East Java Province indicates that there is still very small, with an average of $15.47 \%$ of the total revenue budget. This means that the level of dependence of local governments on the central government is still high. Although the results of regional revenue projections indicate that component has been great in their contribution of the reception area, which amounted to $69.52 \%$. Using the ordinary least squre method, the result of regression correlation are insignificant. This means that the regional gross domestic product does not have an effect on revenue of East Java Province.
\end{abstract}

Key words: Economic Growth, revenues (PAD), Regional Budget (APBD), Gross Domestic Product (GDP)

\section{INTRODUCTION}

utonomy and greater responsibility from central government to local government in principle is intended to assist the central government in governance in general (Davey, 1988 and Hirawan, 1991). In addition, another purpose of granting regional autonomy is to reduce the dependence of local governments on the central government, especially in financial matters, so the area is expected to be able to finance its finances independently. One concern is the local government in the management of revenue from the region itself.

QE Journal | Vol.05 - No. 02 June 2016 - 89 
Enterprises to explore the sources of revenue (PAD) as one source of financing of the authority should be supported by the economic potential of the region as a base owned PAD. This is because the ability of people to pay taxes and levies to the regions highly dependent on the economic activity they do. The higher the economic activities carried out, will increase the income they receive, and along with it the local business to increase revenue through local taxes and levies can be improved.

The role of local revenue (PAD) in the Regional Government reception throughout Indonesia was relatively small to be able to finance regional development. Meanwhile, according to the principle of local autonomy organization of regional governance and development will gradually be increasingly devolved to the regions. With the central government greater authority given to the local government, the role of local government finances will be increasingly important as the area required to be more active in mobilizing its own funds (Bachtiar, 1992). The government's efforts to develop and enhance the role and capacity in the field of economic and financial management of this area, in fact has been launched and started since Pelita I (Insunkindro, 1994).

Local finance is one of the basic criteria to determine significantly the regional power in its own domestic affairs (Kaho, 1995). This automatically implies that the regional government must also implement local finances. Therefore, attention should be focused on efforts - efforts to strengthen the chain of events that can arouse and extend the corresponding relationships in question.

Jaya (1999) stated that the source of development financing is important to note is the reception area itself, because this is the source of which is a form of direct participation of the people of a region to support the development process. The reception area itself is a form of social participation in the form of payment of taxes and levies, should be able to drive regional economic growth, which in turn will increase local revenue.

Implementation of regional autonomy in Indonesia is seen as a strategy that has a dual purpose. First, the granting of regional autonomy is a strategy to respond to the demands of local communities on three main issues, namely the sharing of power, distribution of income, and selfmanagement system in the area. Second, regional autonomy is intended as 
a strategy to strengthen the region's economy in order to strengthen the national economy to the era of free trade (Mardiasmo, 2002).

In order for government-mandated duties of regional autonomy can be carried out efficiently and effectively required financial resources. Financial problems the region is essential and fundamental issues, including the Government of East Java. In providing services to the community, as well as in the framework of regional development in East Java Provincial Government requires operational funding.

One indicator of the decline in the region's dependence on the central government is, increasing the ability of regions in mobilizing resources local revenue sources, both intensification and extension so that the area has significant funds in order to finance regional development in order to improve the welfare of the community. In an effort to increase local revenues derived from the PAD is determined by economic factors or economic potential which has the prospect to be developed for each area. While the economic progress of a region heavily dependent on the development efforts undertaken by the government in providing public facilities to support economic activity.

Enterprises to explore the sources of local revenue, experienced many obstacles, both in terms of lack of financial resources itself and in terms of capabilities and system management and administration. The development of regional development also requires the development of sector revenues this area, which should at least be able to compensate for steps to accelerate the development of local government in the region.

Implementation of regional autonomy is a process that requires the involvement of all elements and segments of society, as well as providing power for regional governments in the area of financial management so that the government's role is as a catalyst and facilitator for the government who are more aware of development goals and objectives to be achieved. As a catalyst and facilitator of course, requires a variety of facilities and support facilities in the framework of the implementation of sustainable development.

Until now, various policies have been taken by the government to develop and enhance regional capability in finance area, as the financial aspects of the area into something that is important, because in order to run the 
administration and regional development funds required or considerable expense.

The economic growth of East Java increased from year to year, is also accompanied by an increase in admission revenue (PAD) as one source of income in financing regional development. So we need further study. Then the problems examined in the study are: analysis of the relationship between the regional economic growths to the growth of revenue (PAD) of East Java Province.

In the relationship between the central government and local governments, Davey (1988) argued that the funding of local government consists of the central government allocation, taxation, fees (charging), loans, and business entities. In the perspective of regional autonomy, PAD become the most important source of finance in addition to other types of reception area which is a translation of the Act No. 33 of 2004 on Financial Balance between Central and Regional.

According to Law No. 34 of 2000 on the Amendment of Act No. 18 of 1997 on Local Taxes and Levies. Article 1, paragraph 6, Local Taxes, hereinafter called the tax is obligatory contribution made by an individual or entity to areas without direct payment are balanced, which can be imposed under the laws in force, which is used to finance the regional administration and regional development.

Slightly different from the Local Tax, according to Kaho (2001) Levies are local taxes as payment for the use of services or for getting the services of a job, business or belong to the area concerned or for services provided by the region. Levies collected by the county, there is a provision of the achievements by the region that are directly appointed, subject to anyone who had received services provided by the region.

According to Law No. 34 of 2000 on the Amendment of Act No. 18 of 1997 on Local Taxes and Levies. Levies the payment of local taxes as above; a) services in the form of business and the services provided by the region, either in the form of public services and business services; $b$ ) licensing of a particular form of permission to an individual with the intention of coaching, managing, controlling and monitoring the activity, utilization, space, use of natural resources, goods and infrastructures, facilities or certain facilities in order to protect the public interest and preserving the 
environment, Both the services and the provision of special permits provided or provided by local governments for the benefit of private persons or entities.

According to Kuznets, economic growth is the increase in long-term capacity of the countries concerned to provide or made possible by the lack of progress or adjustment of various economic goods to its citizens. The increase in capacity itself is determined or made possible by advances in technology or adjustments, institutional (institutional) and ideological to the various demands of the existing situation (see Todaro, 1998).

Economic growth in a nutshell is the increase in output per capita in the long term (Boediono, 1992). This understanding emphasizes on three things: process, output per capita and long term. The process illustrates the development of the economy over time that is more dynamic, output per capita linking aspects of total output (GDP) and the aspect of the total population, while the long term showed a tendency to change the economy in a given period of time is driven by the internal economy (selfgenerating). Economic growth is also defined simply as the increase in total output (GDP) in the long term, regardless of whether the increase was smaller or larger than the population growth rate followed by growth or whether the structure of the economy or not.

In relation to revenues, Peacock and Wiseman (1961) in his theory of the development of government spending is best to conclude that economic development causes tax collection has increased even though the tax rate unchanged and increased tax revenues caused government spending also increased (see Mangkoesoebroto, 1991 ). Therefore, under normal circumstances, the increase in GNP led to greater government revenue, as well as government spending becomes.

Davey (1988) states that one of the criteria for assessing the potential of local taxes is elasticity. Elasticity can be easily measured by comparing the proceeds for several years with changes in the price index, population, or GNP. The GDP is a measure of economic growth that describes the total value of final goods and services produced by the various production units within a region or region in a certain time period. From this it can be seen that the relationship between tax elasticity strip is obtained, and economic growth are judged by the growth of the GDP per capita illustrates the 
automatic growth of tax potential. In other words, in the context of local taxes, the higher the GDP is automatically higher the taxes received area.

Brata (2004), in his study of the composition of local government revenues (Local Government Level I) regional economic growth in Indonesia gave an indication of the Level I Regional Government reception disparity between provinces. Disparities in receipt of components is also visible despite the economic level balanced. The estimation of the results found that not all components of Level I Regional Government reception a positive impact on regional economic growth seen from PBRD per capita. There are also indications that the income component of the local governments more have a strong relationship with the GDP than the GDP of non-oil and gas.

The relationship between the GDP to the local tax is a functional relationship, because local taxes are a function of the GDP, which is by increasing the GDP will increase government revenue from local taxes. Furthermore, with the increase in government revenue boost public services that might be expected to increase the productivity of the people who ultimately can enhance economic growth back. Likewise with increasing economic growth and per capita income, it will encourage the community's ability to pay taxes and other levies.

Tax-related areas that have a positive relationship with economic growth, Musgrave (1991) states that there are three basic base of the central and local taxation. Basic tax base includes local taxes and tax-based facility and corporate income, consumption, and wealth. Based on the opinion of the Fisher, the hotel and restaurant tax, entertainment tax, advertisement tax and street lighting tax categorized local tax based on consumption. In line with the opinion of the Devas et al. (1989) suggested that the tax is the street lighting electricity consumption society.

Peacock and wiseman 1961 stated that economic development led to tax increases, and increasing tax revenues caused government spending also increased (see mangkoesoebroto, 1999). In connection with the role of government to economic growth, miller and russex (1997), examined the effect of fiscal structure on economic growth and municipalities in the united states, said that, first, the increase in the budget surplus will boost economic growth, when spending on education or transportation public can pressed or corporate income tax improved, second, if the sales tax and 
other taxes are used to transfer payment, then economic growth will decrease, but if corporate income tax is used to transfer payment then economic growth will increase, the third, the tax will negatively affect economic growth when state revenue is used to fund education, public transportation and public safety.

Various studies on aspects related to the financial management has often done by previous researchers, among others such as:

Bachtiar (1992) in his research on autonomy and its implications for fiscal capacity in Indonesia by using revenue data across the local Level I of Fiscal Year 1986/1987 and 1990/1991, found some facts. First, that the role of support / donations central government remains at around $60 \%$ in the reception area and PAD increased by about $24 \%$ (1990/1991), the second, from the regression results found that the GDP is one of the factors that affect the amount of revenue from an area. The greater the GDP of a region, the higher revenue from the region concerned. The population is also one of the factors that affect the amount of revenue from an area. However, the effect of population growth is not as big as the effect of the addition of the GDP.

Kuncoro (1995) focuses his observations on the fact that the low revenue of local government financial dependence on the central government is very high. To reduce the central government subsidies, Kuncoro advocated financial autonomy given the relatively broad area so that the area be able to explore their own financial resources and making optimal use.

Kifliansyah in halim (2000), research on the analysis of the realization of budget revenue and expenditure, case studies hulu sungai tengah south kalimantan province, found that the district budget largely funds are still sourced from government allocation / higher institution (the central government and provincial) and the ability to sustain revenue both routine and development expenditures (capex) is relatively low at less than $5 \%$ of total expenditures, hulu sungai tengah dependence on the central government is still very high. 


\section{RESEARCH METHODS}

\section{Data and Data Sources}

The data used to support the writing is secondary data. Secondary data is data obtained through official documents and financial statements of the time series data (time series) of the Fiscal Year 2006 to Fiscal Year 2015 and the data Gross Regional Domestic Product (GDP) of East Java Province.

By using a linear interpolation technique insukindro (2000), this study breaks down the annual data from 2006 to 2015 to the quarterly data from 2006 to 2015. So it can reach a value of $\mathrm{N}$ minimum. The formula is as follows :

$$
\begin{aligned}
Q_{1} & =\frac{1}{4}\left\{Y_{t}-\frac{4,5}{12}\left(Y_{t}-Y_{t-1}\right)\right\} \\
Q_{2} & =\frac{1}{4}\left\{Y_{t}-\frac{1,5}{12}\left(Y_{t}-Y_{t-1}\right)\right\} \\
Q_{1} & =\frac{1}{4}\left\{Y_{t}+\frac{1,5}{12}\left(Y_{t}-Y_{t-1}\right)\right\} \\
Q_{1} & =\frac{1}{4}\left\{Y_{t}+\frac{4,5}{12}\left(Y_{t}-Y_{t-1}\right)\right\}
\end{aligned}
$$

\section{Model Analysis}

Model analysis used in this research is descriptive and quantitative analysis. Descriptive and quantitative analysis aimed at analyzing the development of the local economy and local revenue growth of east java province. Then an analysis tool used is the analysis of quantitative analysis of ordinary least square (ols). To know how to influence the economic development of the acceptance of pad regression analysis. Pad $=\mathrm{f}$ ( $\mathrm{gdp}$ ). The significance of the model will be tested with $r$ square (r2), the $t$ test and f test.

\section{RESULTS AND DISCUSSIONS}

\section{Against the Economic Effect of Regional Revenue}


To see the impact of economic development on revenue is done with a simple regression (simple regression) between Gross Domestic Product (GDP) as the independent variable with revenue (PAD) as the dependent variable. In accordance with the thought that the development of the economy will not affect the increased revenue. This results contrast with the theory. Theory says, the better the economy or increasing the added value generated by each sector in the economy, the ability or the potential for people to pay taxes and levies will increase.

From the result of regression R Square of 1 means increased local revenues are affected by the increase in value added in the economy amounted to $1.4 \%$, which means that economic growth will affect local revenues not entirely. These data indicate that the regional economic development is very low influence on the increase in revenue.

The estimation results by OLS Eviews

\begin{tabular}{lr}
\hline SUMMARY OUTPUT & \\
\hline Multiple R & Regression Statistics \\
R Square & 0.119541 \\
Adjusted R Square & 0.01429 \\
Standard Error & -0.0147 \\
Observations & 0.108576 \\
ANOVA & 36 \\
Regression & \\
Residual & 1 \\
Total & 34 \\
Intercept & 35 \\
X Variable 1 & 3.444797 \\
\hline
\end{tabular}

To see the effect of the independent variable on the dependent variable in this case the influence of economic development to increase local revenue is from the calculated $\mathrm{F}$ or $\mathrm{t}$. From the regression results obtained $\mathrm{F}$ count equal to 0,49 (more than 0,000 ), and t 0,70 which does not has significance level (more than 0,000). Thus it can be said that economic development does not has a significant influence on the increase in local revenues in East Java province. 
From the result of regression is a positive correlation coefficient of 0,57 means that the regional gross domestic product a positive effect on revenue of East Java Province. If an increase in regional gross domestic product by 1 unit will increase revenue amounting to 0,57 It can be concluded that the development of the economy of East Java province has positive effect on revenue of East Java Province. If an increase in the economy, the local revenues East Java province will increase. However, these results cannot be used. Because the regression result insignificant.

\section{Improvement Management Admission PAD in East Java Province}

In order to finance the regional government funded top of and at the expense of the Regional Budget (APBD) of East Java Province, the first concern is how much revenue received by the region. Total realization of local taxes in 2014 reached 11.52 trillion rupiah and are major contributors to the Post Acceptance East Java Regional Revenue amounted to 79.75 percent of the government's efforts to try to explore and develop the potential of the reception area in particular to increase the acceptance of PAD. In the PAD components, from data analysis local tax revenues and levies show, was the increase in local revenues from local taxes over the analysis period is higher than the ratio of the increase in local revenues from levies. This shows that people feel more willing to pay local taxes of the levies, benefits felt directly by the taxpayer.

The most interesting thing to be done by the Provincial Government of East Java in order to reduce the level of financial dependence on the central government, which in turn will be independent in financing the development is the existence of an actor stimulator to increase revenue. If you are still looking forward to the public would never have local revenue exceed $79.75 \%$ of the total regional revenues. This is because the condition of East Java province itself is indeed possible to tax and levy a relatively large area to the public.

Besides those mentioned above is the need to make the area of East Java province as an attractive area to invest. Strategies that can be taken in order to attract investment to the area, first, provide convenience facilities on capital and licensing for industrial activities, secondly, ensure the continuity of material supply of industrial raw, third, ensuring security for businessmen who invest in the region, the fourth, in the field of taxation

QE Journal | Vol.05 - No. 02 June 2016 - 98 
give tax holidays for new industry grows in both the industrial pure managed by private parties or business managed by regional companies, for example, to not impose taxes and levies within one or two years or until the industry or the business has been correctly -Right can operate normally.

\section{CONCLUSIONS AND RECOMENDATIONS}

\section{Conclutions}

Based on the previous description, the research results can be summarized as follows:

Role of Local Revenue (PAD) in the Regional Budget (APBD) of East Java Province indicates that there is still very small, with an average of $15.47 \%$ of the total revenue budget. This means that the level of dependence of local governments on the central government is still high. Although the results of regional revenue projections indicate that this has been a great contribution in the reception area, which amounted to $69.52 \%$.

There is no significant from the result of regression. This means that the increasing or decreasing on amount of the regional gross domestic product does not have an effect on revenue of East Java Province.

\section{Recommendation}

Based on the previous conclusions, some things that can be taken in planning the reception of local revenue in the province of East Java as follows:

To reduce dependence on the area of the central government in terms of local finance for financing the construction, interesting things that can be done is the existence of an actor stimulator to increase revenue, such as by forming a business entity or a local company that manages businesses that possible by the Java Province Government Eastern reliable as a source of revenue.

Government budget expenditures to build infrastructure facilities and basic infrastructure should be further augmented magnitude. Facilities and infrastructure are both indispensable for the development of the business world that will have an impact on economic growth. With the development of the regional economic development, it is expected to increase production

QE Journal | Vol.05 - No. 02 June 2016 - 99 
and ultimately raising funds from the public in the form of taxes and levies will be developed. So there will be a correlation between the increase in economic growth and regional revenue.

\section{REFERENCES}

Ardiyanto, Danis. 2012. Analisa Keterkaitan Pengeluaran Pemerintah Dan Produk Domestik Bruto Di Indonesia : Pendekatan Vector Error Correction Model(Vecm). Jurnal Ilmiah Fakultas Ekonomi Universitas Brawijaya Malang. www.jimfeb.ub.ac.id. Diakses pada 30 September 2015

Badan Pusat Statistik Indonesia. Boklet seluruh provinsi di Indonesia www.bps.go.id. Data Pertumbuhan Ekonomi tahun 2015. Diakses pada 30 September 2015

Buku Data Dinamis Provinsi Jawa Timur Semester I tahun 2015.

Boediono. 2012. Teori Pertumbuhan Ekonomi, Edisi Pertama. Yogyakarta; BPFE

Direktorat Jendral Perimbangan Keuangan Kementrian seluruh provinsi di Indonesia www.djpk.kemenkeu.go.id. Data Daerah Anggaran Provinsi Jawa Timur tahun 2006-2014. Diakses pada 30 september 2015

Djojohadikusumo, Sumitro 1994. Dasar Teori Ekonomi Pertumbuhan dan Ekonomi Pembangunan. Jakarta : LP3ES

Fisanti Atni. 2013 Analisis Faktor - Faktor Yang Mempengaruhi Pendapatan Asli Daerah (Pad) Di Kabupaten Rokan Hulu. Jurnal Penelitian Fakultas Ekonomi Universitas Pengaraian.www.ejournal.upp.ac.id. Diakses pada 30 September 2015

Gujarati, Damodar. 2012. Dasar-dasar Ekonometrika, buku 1 dan 2 edisi 5. Jakarta Salemba Empat

Insukindro, 1992. Insukindro Error Correction Model. Jogjakarta: BPFE UGM.

Jaya, I Putu Ngurah Panji Kartika Dan Dwirandra, A.A.N.B. 2014. Pengaruh Pendapatan Asli Daerah Pada Belanja Modal Dengan Pertumbuhan Ekonomi Sebagai Variabel Pemoderasi. Jurnal 
Akuntansi Universitas Udayana. www.ojs.unud.ac.id. Diakses pada 30 September 2015.

Khusaini, Mohammad. 2006. Ekonomi Publik Desentralisasi Fiskal dan Pembangunan Daerah. Malang; Badan Penerbit Fakultas Ekonomi Universitas Brawijaya.Malang : BPFE Universitas Brawijaya

Peraturan Daerah Nomor 14 Tahun 2014 tentang APBD Provinsi Jawa Timur 2015.

Putro, Nugroho Suratno. 2012.Pengaruh Pertumbuhan Ekonomi, Pendapatan Asli DaerahDan Dana Alokasi Umum Terhadap Pengalokasian AnggaranBelanja Modal (Study Kasus Pada Kabupaten/Kota DiProvinsi Jawa Tengah). Jurnal ilmiah Fakultas Ekonomi Universitas Diponogoro.www.Eprints.undip.ac.id. Diakses pada 30 September 2015.

Undang-undang No 32 tahun 2004 pada Bab III Mengenai Pembagian Urusan Pemerintahan Peyelenggaraan Kewenangan Daerah. www.kpu.go.id. Diakses pada 30 September 2015.

Undang-Undang No 33 Tahun 2004 Mengenai Pendapatan Asli Daerah. www.djlpe.go.id. Diakses pada 30 September 2015.

Sitaniapessy, Harry A.P. 2013. Pengaruh Pengeluaran Pemerintah Terhadap Pdrb Dan PAD. Jurnal Economia, Volume 9. www.journal.uny.ac.id. Diakses pada 30 September 2015.

Sugiyono.2011. Metode Penelitian Kuantitatif Kualitatif Dan R\&D. Bandung: Alfabeta

Sodik, Jamzani. 2007. Pengeluaran Pemerintah Dan Pertumbuhan Ekonomi Regional: Studi Kasus Data Panel di Indonesia. Jurnal Ekonomi Pembangunan vol12. www.jurnal.uii.ac.id Diakses pada 30 September 2015.

Syafrizal 2008. Ekonomi Regional Teori dan Aplikasi. Padang : Badoese Media

Yulianita, Anna. 2008. Analisis Sektor Unggulan Dan Pengeluaran Pemerintah Di Kabupaten Organ Komering Ilir. www.academia.edu. Diakses pada 30 September 2015. 